\title{
LETTER FROM THE EDITOR
}

This year, the Political Science Undergraduate Review (PSUR) moved from being published in both fall and winter semester to an annual edition. This choice represents the input of many, some of whom who have supported the making of this journal since its beginnings in 20I5. This annual edition showcases not only the scholarly accomplishments of our colleagues but also the community that surrounds this ongoing project.

First, I would like to thank the Political Science Undergraduate Association (PSUA) for providing the platform that gives students an introduction to the peer-review process. In particular, I thank Navneet Gidda, PSUA President, for her unwavering leadership and guidance in building the editorial team and making multiple publication choices. To Victoria deJong, PSUA VP Finance, I am grateful for her resourcefulness, which secured grants to fund this project but also her diligence in keeping a larger edition affordable. This year, the VP's of Events championed the peer-review process with Micah Leonida single-handedly executing ArtsCon, a conference offering students the opportunity to present work beyond publication, and Sadia Masud planning a PSUR launch party that has provided authors and editors alike with the recognition they deserve. For these events, I cannot thank you both enough. To Ranya ElSharkawi, VP external, I am indebted to your advocacy that increased awareness of this initiative at the faculty level. Thank you, VP Internal Nina Fourie, for keeping the Editorial Team and I organized over the past year and to VP Communications Leah Naicken for promoting the peer-review process and designing this edition's cover pages. Without this group of women, the final product would not be the same.

This edition has been made possible by the combined efforts of the PSUR Editorial Team. Anusha Kav, Aryssa Hasham, Evan MacDonald, Heather Taskey, and Tristan Turner have all approached the peerreview process with integrity and dedication. The creativity and skill level of this team has instilled the highest quality of academic rigour, elevating the PSUR's quality to a new level. The PSUA is truly privileged to have these individuals who are willing to give their time and efforts into the creation of such an excellent final product.

I would like to extend a thank you to the Organization for Arts Students and Interdisciplinary Studies for awarding us the Arts Student Association Grant. Lastly, to all students who submitted their work to the PSUR this year, thank you. We must recognize that it takes courage to share your work in any academic capacity. I hope you continue to participate in peer-review processes beyond this publication.

Sincerely,

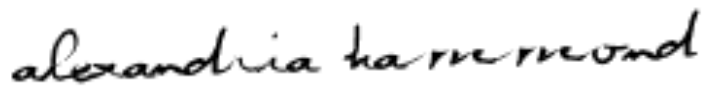

- $\quad$ ALEXANDRIA HAMMOND, Managing Editor and Vice President Academic, 20I7/ı8 